\title{
Study of molecular mechanisms of proapoptotic action of novel heterocyclic 4-thiazolidone derivatives
}

\author{
R. R. Panchuk ${ }^{1}$, V. V. Chumak², M. R. Fil'², D. Ya. Havrylyuk ${ }^{3}$, \\ B. S. Zimenkovsky ${ }^{3}$, R. B. Lesyk ${ }^{3}$, R. S. Stoika ${ }^{1,2}$ \\ ${ }^{1}$ Institute of Cell Biology, NAS of Ukraine \\ 14/16, Drahomanov Str., Lviv, Ukraine, 79005 \\ ${ }^{2}$ Ivan Franko Lviv National University \\ 4, Hrushevsky Str., Lviv, Ukraine, 79005 \\ ${ }^{3}$ Danylo Halytsky Lviv National Medical University \\ 69, Pekarska Str., Lviv, Ukraine, 79010 \\ rpanchuk@ukr.net
}

\begin{abstract}
Aim. Mechanisms of induction of apoptosis signaling pathways in mammalian tumor cells treated by novel heterocyclic 4-thiazolidones with different side groups were studied. Methods. Annexin V/propidium iodide and DAPI (4',6-diamidino-2-phenylindole) staining of cells, Western-blot analysis of specific proteins. Results. 4-Thiazolidone derivatives of various structure possess similar cytotoxic activity in vitro $\left(I C_{50}=5 \mu M\right)$, and induce apoptosis in both leukemia (Jurkat, CCRF-CEM) and carcinoma (MCF-7, MDA-MD-231) cells. Western-blot analysis of the expression of several proteins of apoptosis signaling showed that the structure of lateral groups of 4thiazolidones may directly affect biological activity of these proteins in leukemia cells. In particular, compounds Les-3120 (pyrazoline-substituted thiazolidinone) and Les-3166 (thiazolidinone-benzothiazole conjugate) induced receptor-mediated apoptosis in Jurkat T-leukemia cells. 4-Iminothiazolidinone Les-3372 caused mitochondrial type apoptosis, mediated by AIF protein. Conclusions. Structure-functional relationships between the presence of specific side groups in novel 4-thiazolidones and the signaling apoptotic pathways induced by these compounds have been established. The obtained results allow designing new, «hybrid» compounds which can simultaneously induce more than one apoptotic pathway in tumor cells.
\end{abstract}

Keywords: tumor cells, apoptosis, 4-thiazolidones, caspases, AIF, structure-functional relationships.

Introduction. Recently, 4-thiazolidones and related heterocyclic compounds have been demonstrated to be a perspective source of innovative anticancer agents [1-7]. These compounds are known for their broad biological activity, including antimicrobial, fungicidal, antiviral, and antiinflammatory [5, 7]. Novel pharmacological effects of 4-thiazolidones have been also found, such as antidiabetic and anticancer. This has resulted in the introduction of principally new group of antidiabetic medicines into clinical practice, while potential antitumor effects of 4-thiazolidones are still under investigation $[4,6,8]$.

The previous studies on antitumor activity of 4-thiazolidinone derivatives conducted at the Department of

(C) Institute of Molecular Biology and Genetics, NAS of Ukraine, 2012
Pharmaceutical, Organic and Bioorganic Chemistry of Danylo Halytsky Lviv National Medical University allowed identifying highly active compounds among the 4iminothiazolidinones (Les-3372), pyrazoline-substituted thiazolidinones (Les-3120) and thiazolidinone-benzothiazole conjugates (Les-3166) (Fig. 1). Molecular modeling of these compounds in silico revealed their increased affinity towards antiapoptotic proteins of the Bcl-2 family which are often overexpressed in leukemia and lymphoma cells. Thus, Les-3166 and Les-3120 were tested at the National Cancer Institute (USA) on a panel of 60 tumor cell lines, and their high toxicity towards myeloid cancer cells were revealed. That allowed us to suggest a targeted action of Les-3120, Les-3166 and Les-3372 towards leukemia cells, although the molecu- 
<smiles>[X]Oc1ccc(C2CC(c3ccccc3)=NN2C2=NC(=O)S/C2=C\c2ccc([N+](=O)[O-])cc2)cc1</smiles>

Les-3120<smiles>COc1ccc(NC(=O)COc2ccc(Cl)cc2/C=C2\SC(=S)N(Nc3nc4ccccc4s3)C2=O)cc1</smiles>

Les-3166

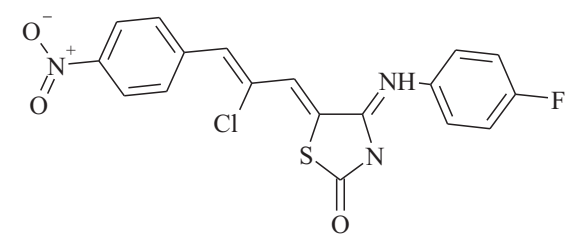

Les-3372
Fig. 1. Structural formulas of studied 4-thiazolidone derivatives lar mechanisms of anticancer activity of these compounds have not been tested yet. The main aim of this work was to study signaling apoptotic pathways in various tumor cell lines under the action of selected 4thiazolidones, and to establish interrelationships between the structure of thiazolidones molecule and the mechanisms of cell death induced in tumor cells.

Materials and methods. Compounds Les-3120, Les3166 and Les-3372 were synthesized at the Department of Pharmaceutical, Organic and Bioorganic Chemistry (Danylo Halytsky Lviv National Medical University). Doxorubicin was bought at the local pharmacy and produced by «Ebeve» (Austria).

Human T-leukemia cells of Jurkat and CCRF-CEM lines were obtained from cell culture collection of R. E. Kavetsky Institute of Experimental Pathology, Oncology and Radiobiology, National Academy of Sciences of Ukraine, human breast adenocarcinoma cells of MCF-7 and MDA-MD-231 lines were obtained from Ludwig Institute for Cancer Research (Sweden). Cells were cultured in the RPMI medium supplemented with $10 \%$ fetal calf serum («Sigma Chemical Co.», USA), $50 \mu \mathrm{g} /$ $\mathrm{ml}$ streptomycin («Sigma Chemical Co.»), 50 units $/ \mathrm{ml}$ penicillin («Sigma Chemical Co.») in $5 \% \mathrm{CO}_{2}$-containing humidified atmosphere at $37^{\circ} \mathrm{C}$.

For experiments, cells were seeded into 24-well tissue culture plates («Greiner Bio-one», Germany). $2 \mathrm{mM}$ stock solutions of each 4-thiazolidone in DMSO (99.5\% pure, «Sigma», USA) were prepared, and additionally dissolved in serum-free culture medium (RPMI for leukemia cells and DMEM for carcinoma cells) prior to addition to the cell culture. Final concentration of DMSO in the cell culture was $0.5 \%$ or less. Cytotoxicity studies on the Jurkat and MCF-7 cells revealed no statistically significant toxicity of $0.5 \%$ DMSO solution towards these cell lines.

Cytotoxic effect of antitumor drugs was studied using the inverted microscope («Biolam-P1», «LOMO», $\mathrm{RF})$ after cell staining with trypan blue dye $(0.1 \%)$.

FITC-conjugated Annexin V («BD Pharmingen», USA) and propidum iodide («Sigma») double staining was performed to detect early apoptotic events under treatment of Jurkat cels by 4-thiazolidones. In 3, 6, 12, $24 \mathrm{~h}$ after the addition of Les-3120, -3166, -3372 , the Jurkat cells were centrifuged at 2,000 rpm, washed twice with $1 \times$ PBS, and incubated for $15 \mathrm{~min}$ in Annexin V binding buffer («BD Pharmingen») containing 1/20 volume of FITC-conjugated Annexin V solution and PI $(20 \mu \mathrm{g} / \mathrm{ml}) .10 \mu \mathrm{l}$ of cell suspension were added to slides and cover glasses were placed. Cytomorphological investigations were performed with Zeiss AxioImager A1 fluorescent microscope («Zeiss», Germany).

DAPI (4',6-diamidino-2-phenylindole) («Sigma») staining was performed for studying chromatin condensation in MCF-7 cells at various time points of the Les$3120,-3166,-3372$ treatment. In 3, 6, 12, and $24 \mathrm{~h}$ after the addition of 4-thiazolidones, the MCF-7 cells were washed twice with $1 \times$ PBS, fixed in $4 \%$ solution of paraformaldehyde for $15 \mathrm{~min}$ at room temperature, and then permeabilized by $0.1 \%$ Triton X-100 solution in PBS for $3 \mathrm{~min}$. After that, the cells were incubated with $1 \mu \mathrm{g} / \mathrm{ml}$ solution of DAPI for $5 \mathrm{~min}$, washed twice with 
PBS and cover glasses with fixed cells were placed on slides. Cytomorphological investigations were performed with Zeiss AxioImager A1 fluorescent microscope.

Western blot analysis was used to evaluate the expression of proteins involved in signaling pathways of apoptosis induced by 4-thiazolidones. After harvesting, cell pellets were incubated with $50 \mu 1$ of lysis buffer (20 mM Tris-HCl, pH 7.5, $150 \mathrm{mM} \mathrm{NaCl,} 0.5 \%$ Triton $\mathrm{X}-100,1 \%$ Trasylol, $1 \mathrm{mM}$ PMSF) per $10^{6}$ cells, vortexed, and centrifuged. Protein concentration in the supernatants was measured, as described [9]. Then $1 / 5$ volume of $5 \times$ Laemmli buffer (10\% SDS, $10 \% 2$-mercaptoethanol, $40 \%$ glycerol, $0.01 \%$ bromphenol blue, 250 мM Tris-HCl, pH 6.8) was added, and samples were heated for $5 \mathrm{~min}$ in boiling water, and subjected to Western-blot analysis. $50 \mu \mathrm{g}$ of protein of each cell sample was loaded onto $12 \%$ polyacrylamide gel. After electrophoresis $(4 \mathrm{~h}$ at $0.02 \mathrm{~A})$, proteins were transferred onto the nitrocellulose membrane ("Amersham Pharmacia Biotech», USA) for $1.5 \mathrm{~h}$ at $90 \mathrm{~V}$ using Mini Trans-Blot Cell («BioRad», Sweden). Incubation of membrane in $5 \%$ milk solution for $1 \mathrm{~h}$ at $37{ }^{\circ} \mathrm{C}$ was used to block nonspecific binding sites. The membrane was incubated with monoclonal rabbit antibodies raised against cleaved caspase-3, cleaved caspase-6, cleaved caspase-7, proteins Bid («Cell Signaling», USA), AIF (sc-5586), Bax (sc-6236), Bcl-2 (sc-492), BclXL/S (sc-634) («Santa Cruz Biotech», USA), caspase9 (BD 556585) («BD Pharmingen»), $\beta$-actin («Sigma»), monoclonal goat antibodies against procaspase-3 (sc1226) ( «Santa Cruz Biotech»), and monoclonal mouse antibodies against caspase-2, caspase-8 («BD Pharmingen»), caspase-10 («MBL», USA) for $12 \mathrm{~h}$ at $4{ }^{\circ} \mathrm{C}$ with slow shaking. Dilution for primary antibodies equaled $1: 1,000$ in $5 \%$ BSA, $0.1 \%$ PBS-Tween, except for antibodies against $\beta$-actin $(1: 5,000)$, as recommended by supplier. After incubation with primary antibody, the membrane was washed three times for $5 \mathrm{~min}$ in $1 \times$ PBS with $0.1 \%$ Tween 20 , and then incubated in 1:5,000 dilution of secondary anti-rabbit IgG horseradish peroxidase-linked antibody («Amersham Pharmacia Biotech») for $1 \mathrm{~h}$ at room temperature. The membrane was washed 3 times for $5 \mathrm{~min}$ with PBS-Tween 20, and proteins that bound antibodies were vizualized by membrane incubation for $1 \mathrm{~min}$ in ECL buffer $(1.25 \mathrm{mM}$ luminol («Sigma»), $2.72 \mathrm{mM}$ cumaric acid («Sigma») and $0.01 \% \mathrm{H}_{2} \mathrm{O}_{2}$ in $0.1 \mathrm{M}$ Tris- $\mathrm{HCl}$, $\mathrm{pH} 8.5$ ), and exhibition for 10-15 min with X-ray film («Fujifilm», Japan). Relative amount of protein in the electrophoretic bands was quantified by using Gel-Pro Image Analysis software («Media Cybernetics», USA). Protein loading normalization was conducted for $\beta$-actin level in the same samples.

Results and discussion. At the first stage of this work, the anticancer activity and effective inhibiting concentration of 4-thiazolidones were evaluated. For this, $\mathrm{LC}_{50}$ index was used, calculated as a lethal concentration of drug, which kills $50 \%$ cells in comparison with a control culture. In Fig. 2, $A, B$, the cytotoxic activity of Les-3120, Les-3166 and Les-3372 towards the human T-leukemia cells of Jurkat and CCRF-CEM lines are shown.

It was found that all compounds under study inhibited proliferation of leukemia cells in dose-dependent mode in $24 \mathrm{~h}$ after their addition to the culture medium. Jurkat cells appeared to be more sensitive towards Les$3120,-3166$ and -3372 , compared to other leukemia cells of CCRF-CEM line. For studying specificity of anticancer activity of 4-thiazolidones, their cytotoxic effect was analyzed using another in vitro model - breast adenocarcinoma cells of MCF-7 and MDA-MD-231 lines. It was revealed that the cells of high-invasive breast adenocarcinoma of MDA-MD-231 line were among the most sensitive to the action of 4-thiazolidones, since $\mathrm{LC}_{50}$ of all tested compounds equaled $1 \mu \mathrm{M}$ (Fig. 2, $C, D)$. However, other carcinoma cells of MCF-7 line were 10 times more resistant to thiazolidones action compared to MDA-MD-231 line. Thus, the cytotoxic activity of these compounds seems to depend on the specificity of each cell line tested. It should be noted, that all three studied compounds (Les-3120, Les-3166 and Les-3372), despite substantial differences in their chemical structure, demonstrated similar indexes of their cytotoxic activity towards tumor cells (Fig. 2). Average $\mathrm{LC}_{50}$ index was very close for all three compounds $5 \mu \mathrm{M}$, however, it was still 10 times higher, than that of the doxorubicin $(0.5 \mu \mathrm{M})$ - anticancer drug which is already used in clinics.

Three main cell death mechanisms have been identified - apoptosis, autophagy, and necrosis [10]. Cell necrosis is undesirable phenomenon during chemotherapy treatment, since it results in development of massive in- 

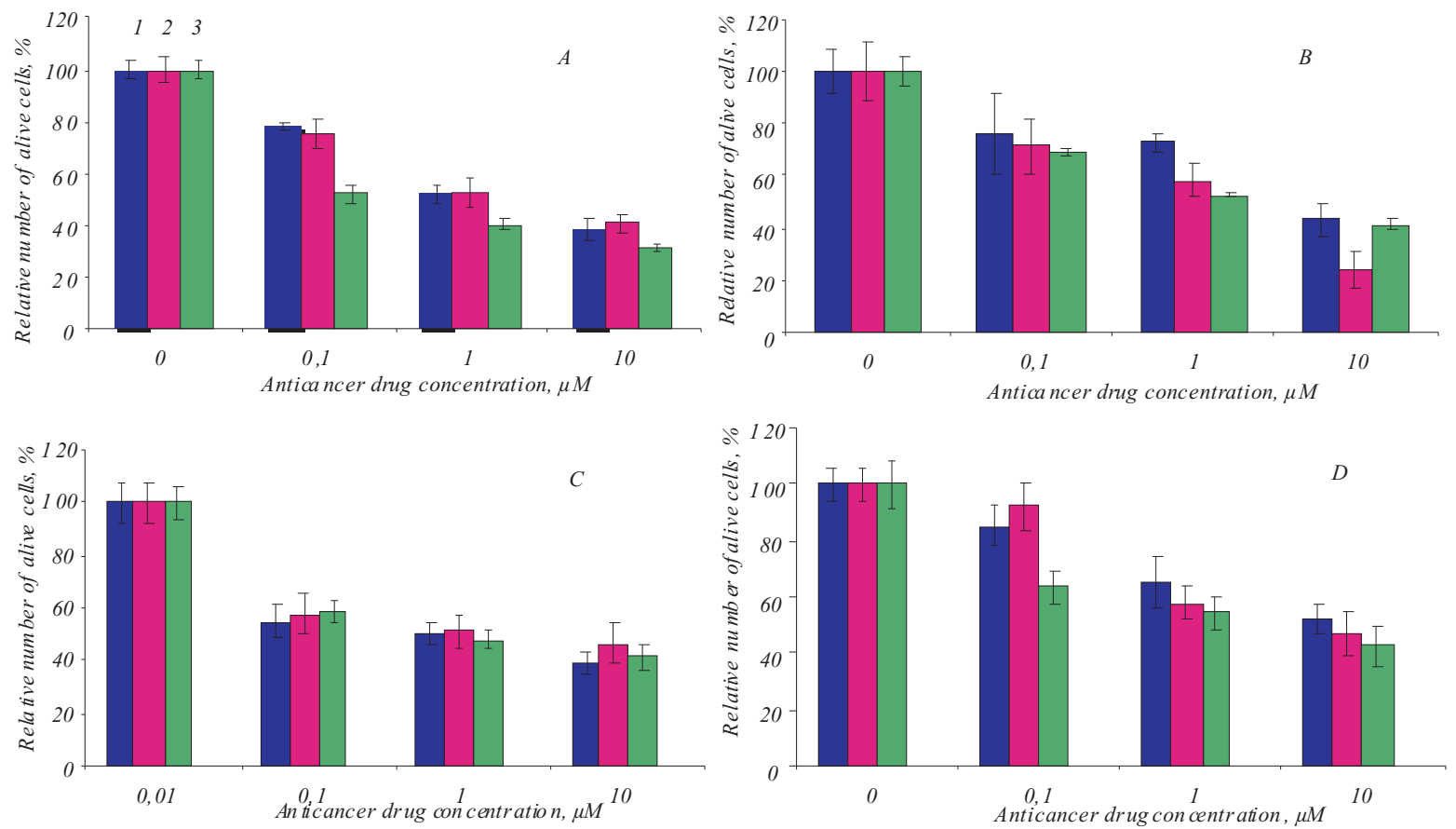

Fig. 2. Cytotoxic effect of Les-3120 (1), Les-3166 (2) and Les-3372 (3) on human T-leukemia cells of Jurkat (A) and CCRF-CEM (B) lines and human breast adenocarcinoma cells of MDA-MD-231 (C) and MCF-7 (D) lines after $24 \mathrm{~h}$ of incubation

flammatory processes in the organism of cancer patients, which can significantly complicate a treatment process. In contrast, the induction of apoptosis by anticancer drugs leads to quick phagocytosis of remnants of tumor cells by the macrophages that considerably diminish the development of side effects of chemotherapy.

Cytomorphologic studies were performed to identify in which way - apoptotic or necrotic - 4-thiazolidones induce death of target cells. Phosphatidylserine translocation to the external layer of the cell membrane of dying cells measured by the Annexin $V$ test is considered to be one of the earliest hallmarks of apoptosis [11]. Propidium iodide is a DNA targeting dye which detects only necrotic cells, since alive cells use membrane pumps to move it outside into the extracellular medium. Supravital double staining of the Jurkat T-leukemia cells, treated with Les-3120, -3166, -3372 (5 $\mu \mathrm{M})$, with FITCconjugated annexin $\mathrm{V}$ and propidium iodide revealed that all tested compounds induced apoptosis in leukemia cells (Fig. 3, see inset). Doxorubicin in comparable concentration $(4 \mu \mathrm{M})$ led to the secondary necrosis.

Chromatin condensation is another important characteristic of apoptosis. It can be easily measured by using the DNA-intercalating dyes, such as DAPI. We have revealed that all three compounds $(10 \mu \mathrm{M})$ cause the development of chromatin hyper-condensation in MCF-7 cells, and also induced apoptosis in carcinoma cells (Fig. 4, see inset). Thus, structurally different members of 4-thiazolidones possessed similar cytotoxic activity and induced apoptosis in both leukemia and carcinoma cells.

Molecular mechanisms of apoptosis induced by anticancer drugs are divided into two main pathways: death receptor (DR)-dependent and DR-independent (mitochondrial) [12]. Extrinsic (receptor-mediated) pathway starts with binding the death receptor (e. g. Fas) by a cognate ligand (e. g. FasL), which causes the recruitment of adaptor proteins (e. g. TRADD and FADD) and initiator procaspase- 8 molecules to the cytosolic side of the receptor to form the death-inducing signaling complex (DISC) [13, 14]. In most cell types (type I), active caspase- 8 activates the executioner caspase-3, which, in turn, is responsible for many of morphological and biochemical manifestations of apoptosis. In other cell types (type II) the amount of caspase- 8 activated within DISC is low and insufficient for direct activation of downstream executioner procaspases, including caspase-3 and -7 [16]. Instead, active caspase- 8 in type II cells is known to cleave the cytosolic BH3-only protein Bid to truncated Bid (tBid) [15]. In turn, tBid can ac- 
tivate the multidomain $\mathrm{Bcl}-2$ family protein (i. e. Bax and Bak) that stimulates the mitochondrial outer membrane permeabilization (MOMP) and the release of intermembrane space proteins into cytosol [17].

A critical event in the initiation of DR-independent apoptosis is mitochondrial dysfunction, which is regulated by the Bcl-2 family proteins [12]. After induction of the apoptotic stimuli by anticancer drugs, the proapoptotic proteins, including Bax, Bak and Bad, are induced in accordance with their sensitivity to the anticancer drugs. The homodimerized Bax acts on VDAC, localized in the outer membrane of mitochondria, resulting in the release of cytochrome $\mathrm{c}$ which activates the caspase cascade [18]. In particular, oligomerization of a cytochrome c/Apaf-1/procaspase-9 complex (apoptosome) leads to caspase-9 activation causing the cleavage of downstream effector caspase- 3 and -7 in the presence of dATP leading to apoptosis [19].

For identification of apoptotic signaling pathways, induced by Les-3120, Les-3166 and Les-3372 in treated tumor cells, Western-blot analysis was performed using 15 antibodies against proteins involved in early and late stages of apoptosis. The sequence of action of initiator and effector caspases, activated under the influence of these compounds, was studied in time-dependent mode at several time checkpoints $(3,6,12,24 \mathrm{~h})$ after drug addition to the culture medium. The Jurkat Tleukemia cells, which are known to be among the most sensitive to thiazolidones action, were used as an experimental model line in these studies. Equal protein loading onto the gel and at Western blotting was assessed after the incubation of membranes with antibodies against $\beta$-actin.

In Fig. 5, the expression of effector and initiator apoptotic enzymes under the action of Les-3120, -3166, and -3372 in the Jurkat T-cells is shown. Doxorubicin $(4 \mu \mathrm{M})$ was used as a positive control. It was revealed that the usage of compounds with different structure of side groups led to various activation of effector caspases. An impact of Les-3120 and Les-3166 did that already in $12 \mathrm{~h}$ after starting treatment, while Les3372 possessing the same $\mathrm{IC}_{50}(5 \mu \mathrm{M})$, caused the activation of caspase- $3,-7$ and subsequent cleavage of PARP1 and DFF45 only in $24 \mathrm{~h}$. This phenomenon can be explained by different mechanisms of the action of these compounds. To confirm this hypothesis, the expressi- on of the initiator caspases and small mitochondrial proteins was analysed.

Les-3120 and Les-3166 also activated caspase- 8 involved in the receptor-mediated apoptosis and subsequent cleavage of Bid protein by caspase- 8 in $12 \mathrm{~h}$, while Les-3372 did not possess such activities (Fig. 5). Another initiator caspase-10, also involved in receptor-mediated apoptosis, was partially cleaved by Les-3120 and Les-3166, but not by Les-3372, in $24 \mathrm{~h}$. The Bid protein is known to be a «bridge» between the cell death receptors and mitochondria, effectively transmitting a signal from the Fas/CD95 receptor to these organelles. Les3372 had no effect on the expression of this protein.

Significant cleavage of procaspase-9, involved in the mitochondrial-type apoptosis, was found only in the cells treated with Doxorubicin (positive control) and Les-3372 (at 24 h), while other compounds (Les-3120 and Les-3372) had weak effect on the expression of this initiator caspase. No statistically significant differences in the expression of proapoptotic mitochondrial Bax protein and antiapoptotic Bcl-xL protein were observed under the action of 4-thiazolidones, while the amount of another mitochondrial protein - AIF (apoptosisinducing factor) - involved in the caspase-independent apoptosis [20], was increased already in $12 \mathrm{~h}$ in Les3372-treated cells.

No changes were found in the expression of procaspase-2 (involved in the intrinsic, endoplasmic reticulum(ER)-mediated apoptosis) [21] under the treatment of Les-3120 and Les-3166, while Les-3372 and Doxorubicin did cleave those proteases. Thus, it is probable that the ER is not important in the Les-3120 and Les3166-induced apoptosis, while in case of Les-3372 both ER and mitochondria could be of high importance.

Summarizing, Les-3120 leads to the activation of procaspase- 8 and to subsequent cleavage by this caspase its substrate - Bid, in $12 \mathrm{~h}$ after the treatment of the Jurkat T-cells. This process is accompanied by the activation of effector caspases-3, -7, and cleavage of DNAreparation enzymes PARP-1 and DFF45 by these caspases. Only weak signs of the caspase-9 activation (involved in the mitochondria-induced apoptosis) were found. Taking into consideration that the Jurkat cells belong to type II, where the mitochondria activation is required for successful induction of the DR-dependent apoptosis [15], we suggest that Les-3120 leads to recep- 


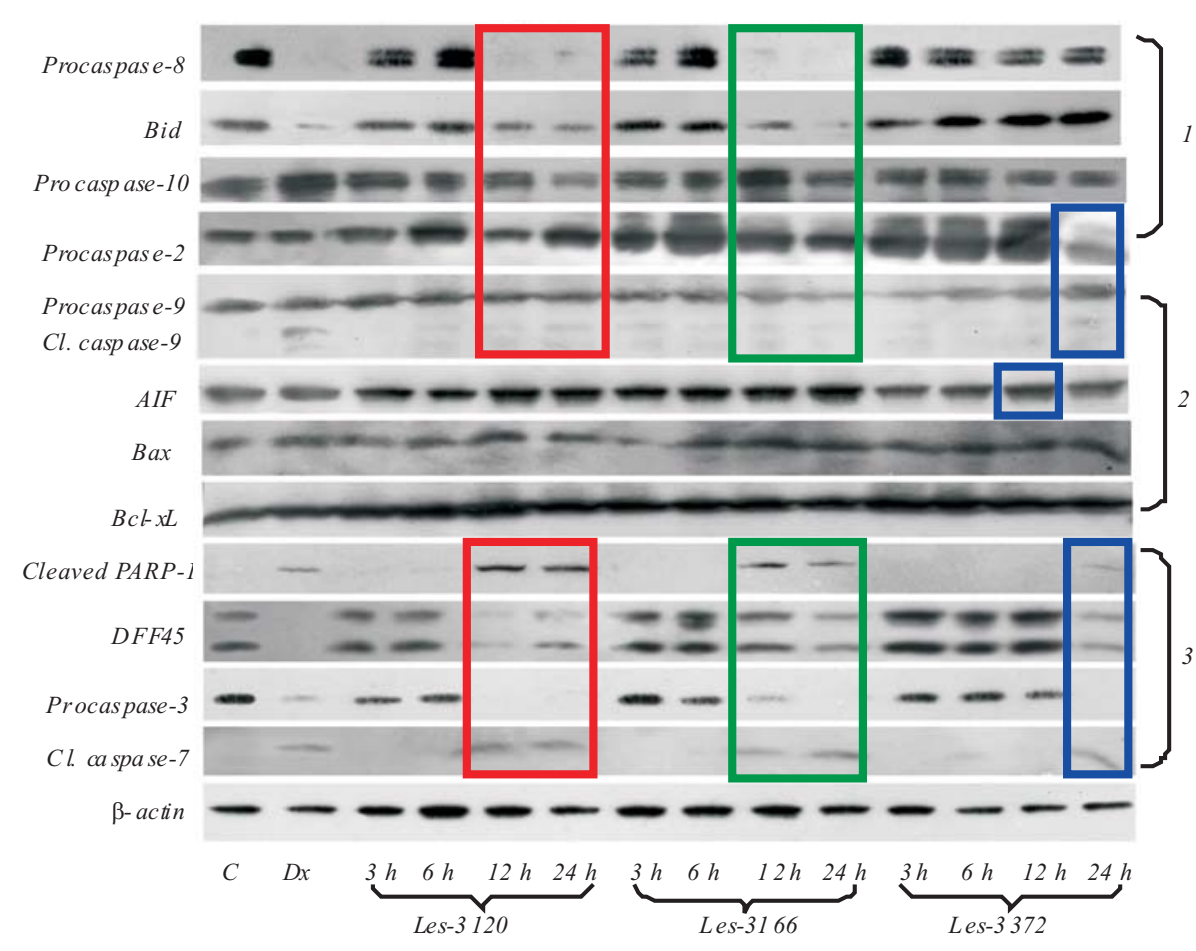

Fig. 5. Expression of proteins involved in initiator and effector stages of apoptosis in Jurkat T-leukemia cells under cytotoxic action of 4-thiazolidones (Western-blot analysis). Concentration of 4-thiazolidones - $5 \mu \mathrm{M}$; Doxorubicin $(D x)-4 \mu \mathrm{M}: 1$ - plasma membrane targeting; 2 - mitochondrial targeting; 3 nuclear targeting

tor-induced, but mitochondria-mediated apoptosis that is arbitrated by caspase- 8 and effector caspases-3, -7 .

Les-3166 also causes early activation of caspase- 8 and Bid in $12 \mathrm{~h}$ after starting treatment. The Bid cleavage and weak activation of caspase- 9 indicate the possible involvement of mitochondria in Les-3166-induced apoptosis. That leads to the activation of the effector caspases-3, -7 by the apoptosome complex, and cleavage of DFF45 and PARP-1 by these caspases. Thus, Les-3166 seems to cause receptor-induced, mitochondria-mediated apoptosis, like Les-3120.

Les-3372, despite the $\mathrm{IC}_{50}$ index, similar to Les-3120 and Les-3166, leads to a weak caspase-7 activation and a weak cleavage of PARP-1 and DFF45 in the Jurkat T-cells only in $24 \mathrm{~h}$ after the addition of drug to the culture medium. A decrease in the level of procaspase-2 (mediator of intrinsic, ER-induced apoptosis) and appearance of cleaved form of caspase-9 (a mediator of the mitochondria-induced apoptosis) were found in $24 \mathrm{~h}$ after Les-3372 treatment. However, a significant increase in the AIF level in $12 \mathrm{~h}$ was the earliest event observed in the case of Les-3372 action (Fig. 5). AIF is known to induce the mitochondria-mediated caspase-independent apoptosis. Thus, Les-3372 leads to the activation of intrinsic apoptotic pathways, mediated by mitochondria, and caspases seem to play a minor role here.

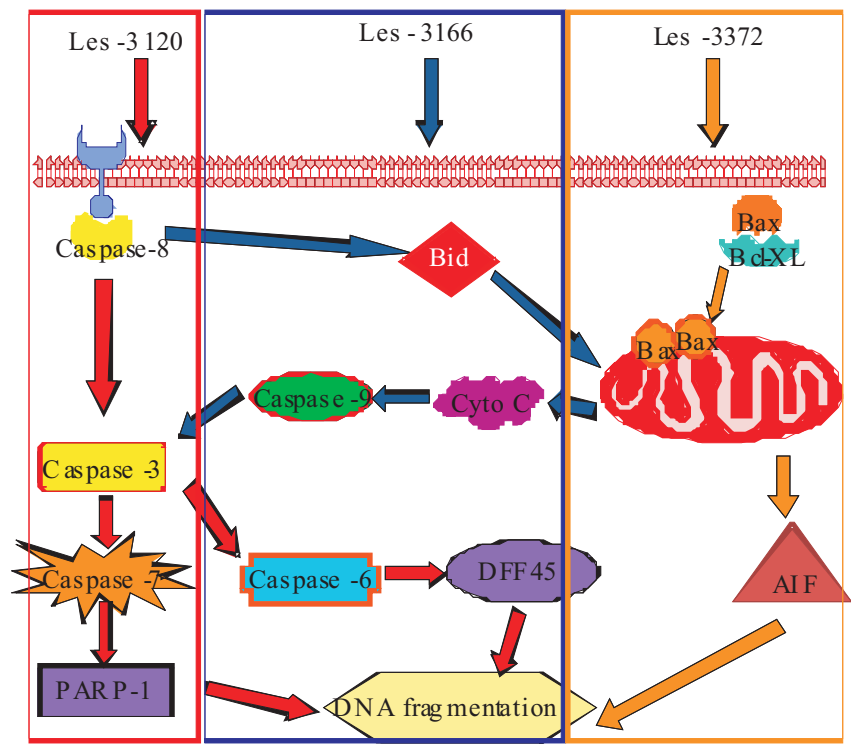

Fig. 6. General scheme of signaling apoptotic pathways, induced by studied 4-thiazolidone derivatives in tumor cells

A scheme of signaling apoptotic pathways induced in tumor cells by different 4-thiazolidone derivatives is shown in Fig. 6.

Conclusions. We suggest that the structure of side groups of novel heterocyclic 4-thiazolidone derivatives can affect not only the anticancer activity of these derivatives, but also the activation of specific signaling apop- 
totic pathways induced by these compounds in tumor cells. Les-3120 and Les-3166 seem to cause the receptor-induced but mitochondria-mediated apoptosis, and Les-3372 may be involved in the caspase-independent, AIF-mediated apoptosis. The data obtained suggest definite relationships between chemical structure of side groups of 4-thiazolidones and molecular mechanisms of their anticancer activity. These data should be of great value at designing novel, «hybrid» thiazolidones combining in their structure lateral groups of different compounds and, thus, being more active comparing to their predecessor «parental» compounds.

Acknowledgements. This work was partially supported by personal grants of the West-Ukrainian Biomedical Research Center (WUBMRC) to R. Panchuk, V. Chumak and D. Havrylyuk in 2010-2012, and Grant of the President of Ukraine \#F32-192/2011 to R. Panchuk.

\section{Р. Р. Панчук, В. В. Чумак, М. Р. Філь, Д. Я. Гаврилюк, \\ Б. С. Зіменковський, Р. Б. Лесик, Р. С. Стойка}

Дослідження молекулярних механізмів проапоптичної дії нових гетероциклічних похідних 4-тіазолідонів

Резюме

Мета. Дослідити механізми індукиії апоптичних сигнальних шляхів новими гетероииклічними похідними 4-тіазолідонів зі структурно відмінними бічними групами у злоякісних клітинах ссавців. Методи. Фарбування клітин аннексином V, йодидом пропідію, DAPI, Вестерн-блот аналіз. Результати. Структурно відмінним похідним 4-тіазолідонів притаманна схожа ичитотоксична активність $\left(I C_{50}=5\right.$ мкM), вони також індукують апоптоз у лейкозних (Jurkat, CCRF-CEM) і карииномних (MCF-7, MDA-MD-231) клітинах. Вестерн-блот аналізом із використанням низки антитіл до білків, функиіонуючих на різних стадіях апоптозу, показано, що структура бічних груп 4-тіазолідонів може безпосередньо впливати на біологічну активність иих апоптичних білків у лейкозних клітинах-мішенях. Зокрема, сполуки Les-3120 (піразолін-заміщений тіазолідинон) та Lеs-3166 (кон'югат тіазолідинону і бензтіазолу) індукують рецептор-опосередкований апоптоз у клітинах Т-лейкемії людини лінії Jurkat. 4-Імінотіазолідинон Les-3372 зумовлює anonтоз мітохондріального типу, опосередкований білком AIF. Висновки. Встановлено структурно-функиіональні взаємозв'язки між специфічними бічними групами у молекулах 4-тіазолідонів та сигнальними шляхами апоптозу, щчо дозволяе конструювати нові, «гібридні» препарати з потенційною здатністю одночасно запускати кілька апоптичних каскадів у клітинах-мішенях.

Ключові слова: пухлинні клітини, апоптоз, 4-тіазолідони, каспази, AIF, структурно-функціональні взаємозв'язки.
Р. Р. Панчук, В. В. Чумак, М. Р. Филь, Д. Я. Гаврилюк,

Б. С. Зименковский, Р. Б. Лесик, Р. С. Стойка

Исследование молекулярных механизмов проапоптического действия новых гетероциклических производных 4-тиазолидонов

Резюме

Цель. Исследовать механизмы индукиии апоптических сигнальных путей новыми гетероииклическими производными 4-тиазолидонов со структурно отличающимися боковыми группами в злокачественных клетках млекопитающих. Методы. Окрашивание клеток аннексином V, иодидом пропидия, DAPI, Вестерн-блот анализ. Результаты. Структурно различающиеся производные 4тиазолидонов обладают схожей изитотоксической активностью $\left(I C_{50}=5\right.$ мкM) и индуцируют апоптоз в лейкозных (Jurkat, CCRF-CEM) и карииномных (MCF-7, MDA-MD-231) клетках. Вестерн-блот анализом с использованием ряда антител к белкам, функиионирующим на разных стадиях апоптоза, показано, что структура боковых групп 4-тиазолидонов может непосредственно влиять на биологическую активность этих проапоптических белков в лейкозных клетках-митенях. В частности, соединения Les-3120 (пиразолин-замещенный тиазолидинон) и Les-3166 (конъюгат тиазолидинона и бензтиазола) индуцируют рецептор-опосредованный апоптоз в клетках Т-лейкемии человека линии Jurkat. 4-Иминотиазолидинон Les-3372 предопределяет апоптоз митохондриального типа, опосредованный белком AIF. Выводы. $У_{C-}$ тановлены структурно-функииональные взаимосвязи между специфическими боковыми группами в молекулах 4-тиазолидонов и сигнальными путями апоптоза, что позволяет конструировать новые, «гибридные» препараты с потенциальной способностью одновременно запускать несколько апоптических каскадов в клетках-митенях.

Ключевые слова: опухолевые клетки, апоптоз, 4-тиазолидоны, каспазы, AIF, структурно-функииональные взаимосвязи.

\section{REFERENCES}

1. Havrylyuk D., Kovach N., Zimenkovsky B., Vasylenko O., Lesyk $R$. Synthesis and anticancer activity of isatin-based pyrazolines and thiazolidines conjugates // Arch. Pharm. (Weinheim.).2011.-344, N 8.-P. 514-522.

2. Havrylyuk D., Mosula L., Zimenkovsky B., Vasylenko O., Gzella $A$., Lesyk $R$. Synthesis and anticancer activity evaluation of 4thiazolidinones containing benzothiazole moiety // Eur. J. Med. Chem.-2010.-45, N 11.-P. 5012-5021.

3. Havrylyuk D., Zimenkovsky B., Vasylenko O., Zaprutko L., Gzella A., Lesyk R. Synthesis of novel thiazolone-based compounds containing pyrazoline moiety and evaluation of their anticancer activity // Eur. J. Med. Chem.-2009.-44, N 4.-P. 1396-1404.

4. Kaminskyy D., Zimenkovsky B., Lesyk R. Synthesis and in vitro anticancer activity of 2,4-azolidinedione-acetic acids derivatives // Eur. J. Med. Chem.-2009.-44, N 9.-P. 3627-3636.

5. Lesyk R. B., Zimenkovsky B. S. 4-Thiazolidones: centenarian history, current status and perspectives for modern organic and medicinal chemistry // Curr. Org. Chem.-2004.-8, N 16.-P. 1547 1579.

6. Lesyk R., Kryshchyshyn A., Zimenkovsky B., Atamanyuk D., Havrylyuk D., Kaminsky D., Khyluk D., Nektegayev I., Subtel'na I., Roman O., Holota S. Anticancer potential of 4-azolidones and 
related heterocycles // Ann. Univ. Mariae Curie-Sklodowska. Med.-2006.-19, N 1.-P. 107-110.

7. Lesyk R., Zimenkovsky B., Subtelna I., Nektegayev I., Kazmirchuk $G$. Synthesis and antiinflammatory activity of some 2-arylamino-2-thiazoline-4-ones // Acta Pol. Pharm.-2003.-60, N 6.P. 457-466

8. Kucukguzel S. G., Oruc E. E., Rollas S., Sahin F., Ozbek A. Synthesis, characterisation and biological activity of novel 4-thiazolidinones, 1,3,4-oxadiazoles and some related compounds // Eur. J. Med. Chem.-2002.-37, N 3.-P. 197-206.

9. Peterson G. L. A simplification of the protein assay method of Lowry et al. which is more generally applicable // Anal. Biochem.-1977.-83, N 2.-P. 346-358.

10. Edinger A. L., Thompson C. B. Death by design: apoptosis, necrosis and autophagy // Curr. Opin. Cell Biol.-2004.-16, N 6.P. 663-669.

11. Vermes I., Haanen C., Steffens-Nakken H., Reutelingsperger C. A novel assay for apoptosis. Flow cytometric detection of phosphatidylserine expression on early apoptotic cells using fluorescein labelled Annexin V // J. Immunol. Methods.-1995.-184, N 1.-P. 39-51.

12. Kim R., Tanabe K., Uchida Y., Emi M., Inoue H., Toge T. Current status of the molecular mechanisms of anticancer drug-induced apoptosis. The contribution of molecular-level analysis to cancer chemotherapy // Cancer Chemother. Pharmacol.2002.-50, N 5.-P. 343-352.

13. Engels I. H., Stepczynska A., Stroh C., Lauber K., Berg C., Schwenzer R., Wajant H., Janicke R. U., Porter A. G., Belka C., Gregor M., Schulze-Osthoff K., Wesselborg S. Caspase-8/ FLICE functions as an executioner caspase in anticancer drug-induced apoptosis // Oncogene.-2000.-19, N 40.-P. 4563-4573.
14. Kischkel F. C., Hellbardt S., Behrmann I., Germer M., Pawlita M., Krammer P. H., Peter M. E. Cytotoxicity-dependent APO-1 (Fas/CD95)-associated proteins form a death-inducing signaling complex (DISC) with the receptor // EMBO J.-1995.-14, N 22.-P. 5579-5588.

15. Shawgo M. E., Shelton S. N., Robertson J. D. Caspase-9 activation by the apoptosome is not required for fas-mediated apoptosis in type II Jurkat cells // J. Biol. Chem.-2009.-284, N 48.P. 33447-33455.

16. Scaffidi C., Fulda S., Srinivasan A., Friesen C., Li F., Tomaselli K. J., Debatin K. M., Krammer P. H., Peter M. E. Two CD95 (APO-1/Fas) signaling pathways // EMBO J.-1998.-17, N 6.P. $1675-1687$.

17. Kim H., Rafiuddin-Shah M., Tu H. C., Jeffers J. R., Zambetti G. $P$., Hsieh J. J., Cheng E. H. Hierarchical regulation of mitochondrion-dependent apoptosis by BCL-2 subfamilies // Nat. Cell Biol.-2006.-8, N 12.-P. 1348-1358.

18. Tsujimoto Y., Shimizu $S$. VDAC regulation by the Bcl-2 family of proteins // Cell Death Differ.-2000.-7, N 12.-P. 1174-1181.

19. Li P., Nijhawan D., Budihardjo I., Srinivasula S. M., Ahmad M., Alnemeri E. S., Wang X. Cytochrome c and dATP-dependent formation of Apaf-1/caspase-9 complex initiates apoptotic protease cascade // Cell.-1997.-91, N 4.-P. 479-489.

20. Gogvadze V., Orrenius S., Zhivotovsky B. Mitochondria as targets for cancer chemotherapy // Semin. Cancer Biol.-2009.-19, N 1.-P. 57-66.

21. Vakifahmetoglu-Norberg H., Zhivotovsky B. The unpredictable caspase-2: what can it do? // Trends Cell Biol.-2010.-20, N 3.P. $150-159$.

Received 15.12.11 
Figures to article by Panchuk R. R. et al.
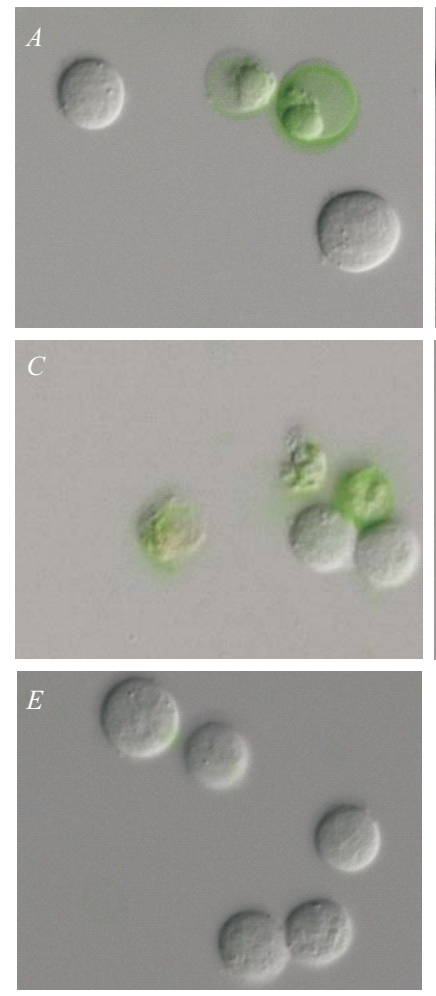
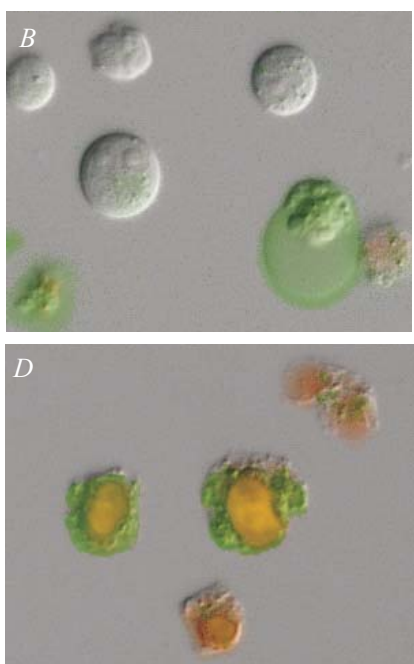

Fig. 3. Proapoptotic activity of 4thiazolidone derivatives (Jurkat $\mathrm{T}$ leukemia cells, annexin V/PI staining, $24 \mathrm{~h}$ )
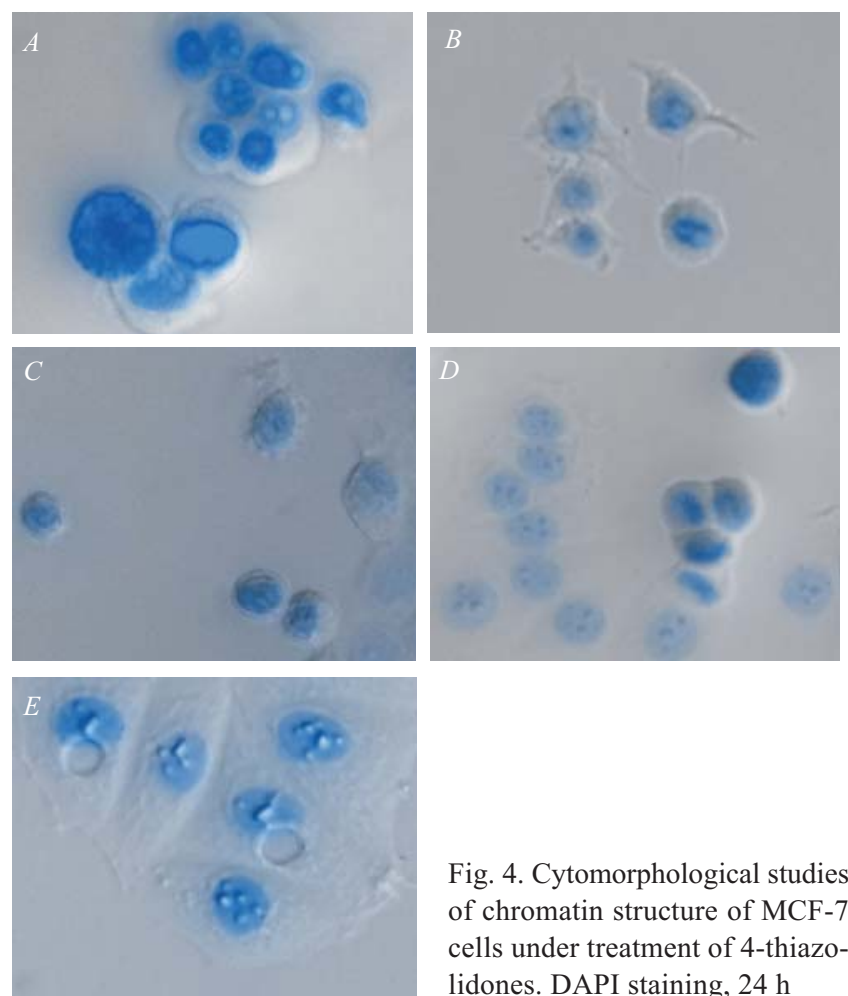

Fig. 4. Cytomorphological studies of chromatin structure of MCF-7 cells under treatment of 4-thiazolidones. DAPI staining, $24 \mathrm{~h}$

Figure to article by Pokholenko Ia. O. et al.
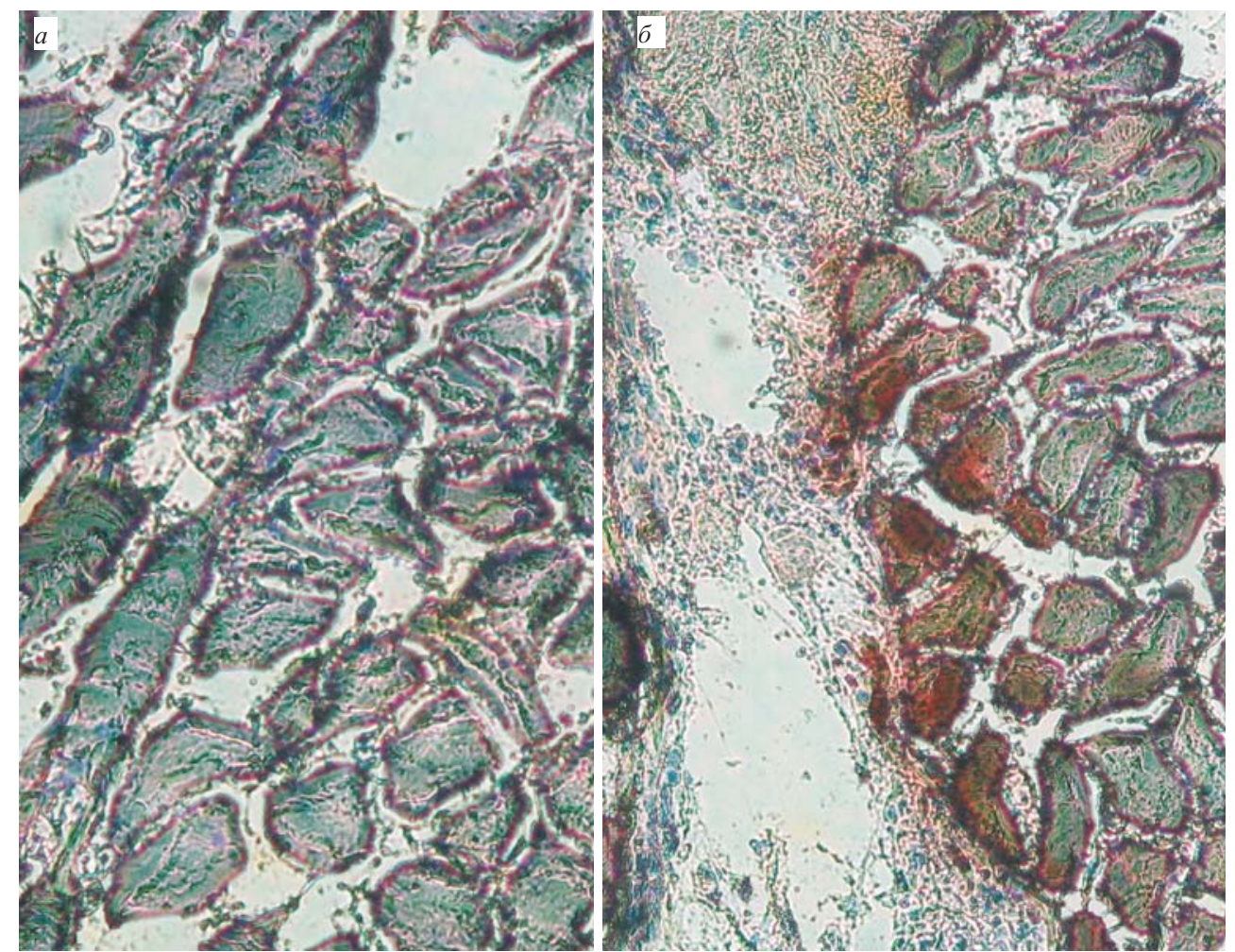

Рис. 3. Иммуногистохимическое определение экспрессии фрагмента гликопротеина Е2 ВКЧС в клетках бицепса мыши на 3-и сут после введения: $a-$ контрольная группа; $\sigma$ экспериментальная группа, которой вводили $p T R-B K n е o^{-}$ $\times 400$ 